\title{
EL COLEGIO PROFESIONAL: UNA ASOCIACIÓN CONSTITUCIONAL
}

ISABEL MARÍN MORAL

Profesora de la Escuela de Relaciones Laborales

Universidad de Burgos 


\section{SUMARIO}

1. La naturaleza jurídica de los Colegios Profesionales. 1.1. La tramitación constitucional del actual art. 36 CE: una referencia obligatoria. 1.2. Falta de definición constitucional del Colegio Profesional. 1.3. La inseguridad en la creación de colegios. 1.4. La legislación autonómica reguladora de los Colegios Profesionales: apuntes constitucionales. 1.5. La exigencia de ley para la creación de Colegios. 1.6. ¿La corporación de derecho público excluye la base asociacional de los Colegios Profesionales? Visión constitucional. 2. LA COLEGIACIÓN OBLIGATORIA. 2.1. Exposición del problema. 2.2. La tutela del interés general. 2.3. El principio pro libertate. 2.4. La aplicación de los criterios jurisprudenciales delTribunal Constitucional a los Colegios Profesionales. 2.5. La STC de 1 de octubre de 1998. 2.6. La doctrina constitucional y la doctrina del Tribunal Europeo de Derechos Humanos. 3. CoLEgios PROFESIONALESY SINDICATOS. 3.1. Dos asociaciones constitucionales diferentes con puntos en común. 3.2. La defensa del interés de la profesión: dos ejemplos de confluencia. 3.2.1. Introducción. 3.2.2. La legitimación procesal. 3.2.3. La legitimación en la negociación colectiva. 3.3. La limitación que ejerce el Colegio Profesional en el derecho de libertad sindical. 4. A MODO DE CONCLUSIONES. 


\title{
EL COLEGIO PROFESIONAL: UNA ASOCIACIÓN CONSTITUCIONAL
}

\author{
POR \\ ISABEL MARÍN MORAL \\ Profesora de la Escuela de Relaciones Laborales \\ Universidad de Burgos
}

\section{LA NATURALEZA JURIDICA DE LOS COLEGIOS PROFESIONALES}

\subsection{La tramitación constitucional del actual art. $36 \mathrm{CE}$ : una referencia obligatoria}

Una de las novedades que contempla nuestra Carta Magna con respecto al constitucionalismo histórico español es el reconocimiento expreso, en el art. $36 \mathrm{CE}$, de los Colegios Profesionales, en los siguientes términos: "La ley regulará las peculiaridades propias del régimen jurídico de los Colegios Profesionales y el ejercicio de las profesiones tituladas. La estructura interna y el funcionamiento de los Colegios deberán ser democráticos».

Se trata de un precepto incluido en la sección segunda del capítulo segundo de la Constitución y, su ubicación concreta entre el derecho del trabajo (art. 35) y el derecho al conflicto colectivo y negociación colectiva (art. 37), derechos propiamente laborales, siendo el precepto de Colegios Profesionales, en un inicio, difícilmente encuadrable en dicha clasificación.

El Anteproyecto Constitucional no contenía referencia expresa a los Colegios, mención que se incluyó en la Comisión del Congre- 
so ${ }^{1} y$, concretamente, en la redacción del art. 7 CE de la siguiente manera: "Los sindicatos de trabajadores, las asociaciones empresariales, los Colegios y demás organizaciones profesionales contribuyen a la defensa y promoción de los intereses económicos y sociales que les son propios. Su creación y el ejercicio de su actividad son libres dentro del respeto a la Constitución y a la ley. Su estructura interna y funcionamiento deberán ser democráticos".

Este artículo 7 CE posteriormente quedó exclusivamente referido a los sindicatos de trabajadores $y$ asociaciones empresariales, reconociéndose a los colegios y organizaciones profesionales en otros preceptos, con distinto alcance jurídico, fuera del marco preliminar de la Constitución, que son los arts. 36 y art. 52, con una redacción definitiva dada no por el Congreso o el Senado, sino por la Comisión Mixta².

Las consecuencias de este cambio de ubicación y reconocimiento son de indiscutible trascendencia, siendo relevantes aspectos como la naturaleza asociativa de los Colegios Profesionales y la cuestionada adscripción obligatoria.

\subsection{Falta de definición constitucional del Colegio Profesional}

La redacción del art. 36 CE no es la clásica de reconocimiento de derechos ${ }^{3}$, a pesar de estar previsto en la sección segunda del capítulo segundo de la Constitución, "De los derechos y deberes del ciudadano". No existe estrictamente el "derecho a un Colegio Profesional» ni «la libertad profesional colegial».

El precepto constitucional no enuncia que los ciudadanos titulados tienen el derecho y deber de estar en un Colegio Profesional, o que los ciudadanos pueden fundar y asociarse a Colegios profesionales, que es lo que habria de esperar por su ubicación. Antes bien, se hace únicamente una encomienda al legislador para que

1 BOC 1 de julio de 1978.

2 BOC 28 de octubre de 1978.

3 En los preceptos de la sección segunda se reconoce: el derecho y deber de defender a España, el deber de sostener al gasto público de acuerdo a la capacidad económica, el derecho a contraer matrimonio el derecho a la propiedad privada y a la herencia, el derecho a la fundación, el derecho y deber de trabajar, el derecho a la negociación colectiva laboral y el derecho a la libertad de empresa. 
regule las peculiaridades propias del régimen de los Colegios, un enunciado amplio en el que caben las más diversas fórmulas de Colegios Profesionales, con la única limitación expresa constitucional de que tanto la estructura interna como el funcionamiento de los Colegios sea democrático.

Por ello, al no ser el art. 36 CE expresamente reconocedor de derechos ha de cuestionarse si la ubicación constitucional de los Colegios Profesionales es la adecuada o, si por el contrario, se deberían haber previsto, si se consideran relevantes para su constancia expresa, en otro título de la Constitución. Como se ha expuesto, en el Anteproyecto de la Constitución figuraban junto con los sindicatos en el art. 7. Esta ubicación les habria supuesto la consideración de asociaciones de relevancia constitucional, en paralelismo con los partidos políticos. Sin embargo, es de considerar acertada la postura del Constituyente de excluirlos de aquel precepto, dado que el Colegio Profesional no puede considerarse institución básica del Estado, junto con las Fuerzas Armadas, los sindicatos y los partidos políticos.

Más adecuado hubiera sido encuadrarlos en el Capítulo III «De los principios rectores de la política social y económica", donde están, entre otras, las organizaciones profesionales y las asociaciones de consumidores y usuarios. El fundamento se encontraría en que los poderes públicos han de promover y garantizar que los profesionales titulados tengan sus organizaciones específicas, a las que ha de oír en aquellas cuestiones que les pueda afectar $y, a$ través de las cuales se proceda a una mejor formación práctica de profesionales así como a una defensa de la profesión, lo que ha de redundar en una mejora socioeconómica.

Por otro lado, en la Constitución tampoco existe una definición de qué es un Colegio Profesional. No se califica al Colegio Profesional como asociación, ni corporación de derecho público, ni de otra manera. No se vincula al Colegio Profesional con titulaciones determinadas ni con profesionales concretos como médicos, abogados o arquitectos.

El Colegio Profesional está abierto, por lo tanto, a la interpretación que de él exista en cada momento. Incluso podría cuestionarse, a la vista del art. $36 \mathrm{CE}$, la obligatoriedad de que el Colegio esté vinculado necesariamente a profesiones tituladas, ya que el constituyente lo que ha hecho ha sido encomendar a la ley, por un lado, la regulación de las peculiaridades propias del régimen jurídico de los Colegios Profesionales y, por otro, el ejercicio de las profesiones titu- 
ladas $^{4}$. Sin embargo, con una interpretación sistemática del precepto hay descartar que pueda existir un colegio de profesionales no titulados.

La Constitución asume el significado que tenían los Colegios Profesionales en el momento de su aprobación, como corporaciones de derecho público ${ }^{5}$. Pero como dice Sainz Moreno6, la interpretación del concepto deber partir de aquél, pero «teniendo en cuenta que los constituyentes no han querido consolidar el régimen jurídico entonces vigenten. El significado que tenían no tiene por qué ser necesariamente acorde con la Constitución. Así, de igual manera que asociaciones de índole obligatoria y gran enraizamiento en la población española como las Cámaras agrarias o la Cámara de la propiedad urbana tenían un significado que se ha cambiado a la luz de la Constitución 7 , los Colegios Profesionales pueden y es de considerar que tienen que adaptar sus viejos postulados a la vigente Constitución, sin que la tradición del Colegio profesional o la relevancia del mismo sea suficiente para impedir o truncar la aplicación de derechos fundamentales.

En este sentido el Tribunal Constitucional ha tenido ocasión de manifestar que el legislador a la hora de crear y configurar las corporaciones de derecho público se encuentra limitado por los mandatos constitucionales, y que "no pueden identificarse como tales límites ni el mantenimiento de las características tradicionales de estas corporaciones si no viene asi dispuesto en la Constitución, ni la necesidad de que el legislador se atenga forzosamente a las decisiones y normas configuradoras en un momento histórico determinado" ${ }^{8}$. No hay que olvidar en relación a este último aspecto, que en el ámbito nacional la Ley 2/1974, de 13 de febrero, reguladora de los Colegios Profesionales, es preconstitucional.

4 Existen otros preceptos constitucionales que recogen más de un derecho en un sólo apartado, como el art. 18.1 CE que reconoce el derecho al honor, a la intimidad personal y familiar y a la propia imagen.

5 SSTC 76/1983, de 5 de agosto; 23/1984, de 20 de febrero; 123/1987, de 15 de julio; 69/1985, de 30 de mayo, y 168/1985, de 13 de diciembre.

6 SAINz MoReno, F:: "Comentario al art. 36 CE", en Comentarios a la Constitución Española de 1978, dir. O. Alzaga, Edersa, Madrid, 1996, pág. 633.

7 Declarándose contrarias al art. 22 CE: SSTC 132/1989 y 139/1989 (Cámaras agrarias), STC 179/1994 (Cámaras de comercio), STC 113/1994 (Cámaras de la propiedad urbana).

8 STC 132/1989, de 18 de julio. 


\subsection{La inseguridad en la creación de colegios}

El art. 36 CE no declara el libre derecho de los ciudadanos o de los profesionales a la creación de colegios, ni impone reglas para su constitución. Por su parte, el art. 4 LCP prevé que la creación de Colegios Profesionales se hará mediante Ley, a petición de los profesionales interesados, pero no establece los requisitos necesarios que se han de reunir para que se pueda solicitar esa creación, cuántos profesionales pueden hacer dicha petición, qué tipo de profesionales o qué intereses o bienes constitucionales tienen que preservar.

Antes de la reforma de la ley operada por la Ley 74/78, de 26 de diciembre, los Colegios Profesionales sólo podían constituirse por titulados universitarios en cualquiera de sus grados (art. 1.2.c). Esta delimitación subjetiva fue derogada, razón por la que cualquier titulado, sea o no universitario, podría inicialmente solicitar la creación de un nuevo Colegio, lo que conduce a una ampliación indeterminable de posibles nuevos Colegios Profesionales.

Por otro lado, aunque suele canalizarse la iniciativa de los titulados a través de asociaciones libres con carácter previo, éstas no son necesarias. Basta en principio con una petición de un número indeterminado titulados. Esto puede ocasionar la creación de innumerables Colegios, unos representativos y otros no de los intereses reales de los profesionales afectados.

Pero lo más criticable de la ley es la falta de previsión de los requisitos de hecho que se necesitan para la creación de un Colegio. No se establecen criterios, sino que éstos se dejan al arbitrio de las Cortes, lo que supone una manifiesta inseguridad en la petición y un cauce abierto para la arbitrariedad política e injerencia estatal, lo cual choca frontalmente con los derechos fundamentales.

Un problema añadido es la dificultad real que se plantea para poder recurrir la creación contraria a la Constitución de un Colegio, ya que al haberse creado por Ley impide al ciudadano afectado la presentación de recurso, sin perjuicio de las dificultades existentes para posteriormente llegar hasta el Tribunal Constitucional, dada su doctrina de deslindar el derecho de los Colegios Profesionales del derecho de asociación.

Esta situación tendria fácil solución con la aplicación de la Constitución. Manteniendo que los Colegios Profesionales son asociaciones específicas y la aplicación subsidiaria del art. $22 \mathrm{CE}$, la creación de aquellos ha de ser libre, sin injerencias estatales. Tan sólo sería nece- 
saria la redacción de la ley que definiera las peculiaridades de los Colegios, en el marco del art. $36 \mathrm{CE}$, donde habrían de reflejarse los requisitos que ha de reunir toda asociación que quisiera ser considerada como Colegio Profesional. La intervención de los poderes públicos se limitarían a la constatación de esos requisitos mínimos. Por otro lado, quedaría abierta la vía para que todo ciudadano afectado pudiera reclamar tutela judicial e incluso plantear recurso de amparo si el Colegio que se crea no respeta los derechos fundamentales, especialmente el art. 22 CE.

\subsection{La legislación autonómica reguladora de los Colegios Profesionales: apuntes constitucionales}

En la actualidad junto con la LCP de 1974 existen variadas legislaciones autonómicas que regulan los Colegios Profesionales dentro de su ámbito territorial, en el marco competencial de los respectivos Estatutos de Comunidad Autónoma. Es el caso, por ejemplo, de la ley castellano-leonesa de 8 de julio de 1997, que regula la constitución de colegios, sus funciones y normas de organización, normas de colegiación y disposiciones sobre Consejos Profesionales de Castilla y León.

Estas legislaciones autonómicas deben respetar la Constitución asi como la legislación básica del Estado, cuestión que suscita interrogantes a la vista del art. 53.1 CE, que impone que la regulación del ejercicio de los derechos previstos en el Capítulo II, donde se prevén los Colegios Profesionales, será por ley que deberá respetar en todo caso su contenido esencial. Dado que el art. 36 CE no reconoce como tal un derecho, como ya se ha expuesto, difícilmente podrá determinarse su contenido esencial y, por tanto, podrá discernirse sobre el alcance de las distintas regulaciones autonómicas.

Si se parte de que el Colegio Profesional es una asociación, tesis que se mantiene, el contenido esencial sería aquel que se predica del art. 22 CE con las especificidades de los Colegios en materia de autoorganización modalizada por criterios democráticos. Ese contenido esencial del derecho de asociación deberá estar previsto en la ley que lo desarrolle y revestirá forma de ley orgánica. Por otro lado, tendría que haber una regulación legal estatal del ejercicio del derecho respetando su contenido esencial, de acuerdo con el art. 53.1 CE, que fuera por tanto igual para todas las Comunidades Autónomas y, que podría ser la propia ley que regule el art. $22 \mathrm{CE}$ (que hasta el momento es preconstitucionall. 
Esa regulación legal no tiene porqué coincidir con la prevista en el art. $36 \mathrm{CE}$, que se refiere exclusivamente a las peculiaridades de régimen jurídico de los Colegios Profesionales y no al ejercicio del derecho, y que permitiría a las Comunidades Autónomas, en el marco de sus competencias, regular las peculiaridades de aquél, si bien debiendo tener en cuenta la regulación mínima estatal sobre el ejercicio del derecho, las limitaciones y obligaciones que imponen la colegiación única estatal, que supone una uniformidad mínima en el sistema colegial, así como la libertad de establecimiento y libre prestación de servicios previstas en el Tratado de la Unión Europea.

\subsection{La exigencia de ley para la creación de Colegios}

Exige el art. 4.1 LCP que la creación de nuevos Colegios Profesionales se haga a través de ley, por lo que dicho precepto vincula al legislador posterior. Los interrogantes que se plantean son, por un lado, si la ley estatal vigente vincula al legislador autonómico y por otro, si puede la LCP obligar al futuro legislador, estatal o autonómico, a que los Colegios los regule por otra ley.

De acuerdo con lo ya visto, es posible que exista legislación autonómica en materia colegial, ahora bien, para que el sistema funcione habría de tenerse como referencia el art. 22 CE: su desarrollo legal por vía ley orgánica y del ejercicio del derecho, vía ley ordinaria. Con ese mínimo, se dejaría a las Comunidades Autónomas la posibilidad de regular las peculiaridades del régimen jurídico de los Colegios profesionales.

Sin embargo, si se omite toda referencia al art. $22 \mathrm{CE}$, nos encontraríamos con una legislación estatal, la LCP, que no desarrolla el contenido del derecho ni regula el ejercicio del mismo, porque el art. 36 CE no enuncia ningún derecho de forma expresa, tampoco se puede considerar como legislación básica estatal. Por lo tanto, la LCP se correspondería con la ley exigida por el precepto constitucional de regulación de peculiaridades del régimen jurídico, sin perjuicio de tratarse de una ley preconstitucional. Junto a esta ley estatal existen las leyes autonómicas constitucionales, lo que plantea importantes interrogantes.

Si rigiese el principio de jerarquia normativa entre la ley estatal y la ley autonómica no existiría problema, ya que ésta debería respetar el contenido de la primera. Sin embargo, tan ley es la estatal como 
la autonómica y no rige el principio de jerarquía entre ellas, sino el principio de competencia9.

Con dicha premisa, si una Comunidad Autónoma tiene competencia para regular los Colegios Profesionales resultaría que se regiría por su legislación autonómica y no por la Estatal. Pues bien, si en aquélla decide que los Colegios se crean a través de fórmula distinta que la prevista en la estatal, sería jurídicamente correcto, de igual manera que si decide que se crean por ley, como establece el art. 6 de la ley de Colegios Profesionales de Castilla y León.

Por ello, pudiera ocurrir que existieran diferentes regulaciones autonómicas, que contemplaran la figura del Colegio Profesional de manera completamente diferente a la que está actualmente en la LCP, ya que las legislaciones autonómicas, en la práctica, regulan contenidos como la forma de su creación o su funcionamiento. Esta posible situación desvirtuaría completamente el panorama jurídico actual en materia colegial.

El legislador de la LCP no vincula al legislador actual autonómico, que también regula por ley. En este caso, la ley posterior deroga a la anterior, sin que exista jerarquía entre ellas por razón territorial. Por consiguiente, debe plantearse la necesidad de que el sistema jurídico de los Colegios Profesionales se aclare. Si se consideran a estas organizaciones como asociaciones estos problemas desaparecerian.

El otro interrogante planteado es si, obviando el tema territorial, el legislador de la LCP puede obligar a que el legislador futuro, estatal o autonómico, tenga que crear colegios profesionales también por ley, ya sea estatal o autonómica. Esta cuestión inicialmente tiene difícil justificación.

\section{6. ¿La corporación de derecho público excluye la base asociacional de los Colegios Profesionales? Visión constitucional}

De acuerdo con el Tribunal Constitucional ${ }^{10}$ los Colegios Profesionales son corporaciones de derecho público. Ahora bien, dicha caracterización no proviene de la Constitución, que remite a la ley para

9 Muñoz MACHADO, S.: Las potestades legislativas de las Comunidades Autónomas, Civitas, Madrid, 1979, págs. 61 y ss.

to STC 76/1983, de 5 de agosto; 23/1984, de 20 de febrero; 123/1987, de 15 de julio. 
la regulación de sus peculiaridades, sino que es el legislador quien puede optar por una configuración determinada. La Constitución permite otras fórmulas diferentes a las de las corporaciones de derecho público, como pueden ser la de entidades privadas de relevancia pública que existen en otros países ${ }^{11}$ o la simple asociación de profesionales titulados.

En la actualidad, la preconstitucional Ley de Colegios Profesionales de 1974, en su art. $10^{\circ}-1$. enuncia que: "Los Colegios Profesionales son Corporaciones de derecho público, amparadas por la Ley y reconocidas por el Estado, con personalidad jurídica propia y plena capacidad para el cumplimiento de sus fines".

El propio Tribunal Constitucional ha mantenido que «interesa recordar que la Constitución no impone en su artículo 36 un único modelo de Colegio Profesional. Bajo esta peculiar figura con rasgos asociativos y corporativos pueden englobarse por el legislador situaciones bien distintas, como son las que corresponden al ejercicio de funciones públicas en régimen de monopolio o de libre concurrencia en el mercado como profesional liberal, y con colegiación forzosa o libre...."12, añadiendo que, " por lo demás, es claro, y así lo hemos dicho reiteradamente, que de la Constitución sólo se deduce que los colegios han de ser regulados por ley, pero ello no excluiría forzosamente que el legislador decidiese regular en una norma específica algunas normas singulares de un o unos Colegios Profesionales (...). No hay en la Constitución ningún precepto que establezca en favor de los Colegios Profesionales, una concreta reserva material indisponible para el legislador, ni tampoco materias consustanciales a los Colegios Profesionales" 13 .

A pesar de lo expuesto, el Tribunal Constitucional defiende el Colegio Profesional como corporación de derecho público, ya que estas «corporaciones cumplen a la vez fines públicos y privados, pero integrados siempre en la categoría o concepto de corporación, al que, al hablar de las personas jurídicas, ya se refería el art. $35 \mathrm{CC}(\ldots)$, dis-

11 Rodríguez Piñero Royo, M.: “Colegios profesionales y Constitución, $R L$, n. ${ }^{\circ}$, 1993, pág. 5 .

Por su parte, OJEDA AVILÉs dice que el carácter público y la afiliación forzosa en los Colegios profesionales no se contempla por la Constitución y pueden en cualquier momento sucumbir en las próximas leyes ordinarias. En Derecho sindical, 5. ed., Tecnos, Madrid, 1990, págs. 139 y ss.

12 STC 330/1994, de 15 de diciembre.

13 STC 336/1993, de 20 de diciembre. 
tinguiendo asi las asociaciones de interés público, las asociaciones de interés particular y las Corporaciones, siendo éstas siempre de carácter público o personas jurídicas públicas, porque pese a la base común asociativa de todas las personas jurídicas, persiguen fines más amplios que los de simple interés particular o privado, concediéndoseles por ello, legalmente, ciertas atribuciones o potestades (especie de delegación del Poder Público) para que puedan realizar aquellos fines y funciones, que no sólo interesan a las personas asociadas o integradas, sino a las que no lo están, pero que pueden verse afectas por las actuaciones del ente" ${ }^{14}$.

Con ello, el Tribunal Constitucional asume la separación entre asociación y corporación ${ }^{15}$, postura sostenida por Garrido Falla ${ }^{16}$ que diferencia entre asociaciones y colegios según las funciones, de tal manera que mientras los colegios de adscripción forzosa atenderían en exclusiva a los intereses objetivos de la profesión concebida casi como un servicio público, las asociaciones voluntarias asumirían la defensa de los intereses materiales de sus miembros.

Ahora bien, al margen de algunas funciones públicas, como dice Torres del Moral17, los Colegios cumplen funciones privadas, asumiendo incluso algunas que no afectan en absoluto a la profesión, por lo que los criterios de diferenciación enunciados se han de considerar incorrectos.

ElTribunal Constitucional en su sentencia 67/85 declaró que el art. $22 \mathrm{CE}$ "no comprende el derecho a constituir asociaciones para el ejercicio de funciones públicas de carácter administrativo relativas a un sector de la vida social». Sin embargo, esas funciones no son todas las que tienen los Colegios Profesionales. Éstos desempeñan unas funciones claramente privadas, que se aprueban bien en Estatutos, asambleas o Juntas de Gobierno, en consonancia con la libertad de autoorganización que propugna el derecho de asociación de nuestra Carta Magna. Si sólo ostentara funciones públicas bastaría

14 STC 89/1989, de 11 de mayo.

15 STC 20/1988, de 18 de febrero, dice que el sentido del art. 36 CE es singularizar a los Colegios Profesionales como entes distintos de las asociaciones que puedan libremente crearse al amparo del art. $22 \mathrm{CE}$, remitiendo la CE a la ley para que ésta regule las peculiaridades de aquéllos.

16 Garrido FalLA, F: "Comentario al art. 36 CE", obra citada, pág. 454.

17 Torres del Moral, A.: Principios de Derecho Constitucional Español, 4. ${ }^{a}$ ed., Servicio de Publicaciones de la Facultad de Derecho de la Universidad Complutense, Madrid, 1998, pág. 346. 
con que los Colegios se rigieran únicamente por ley. No serian necesarios estatutos aprobados por colegiados, asambleas y reuniones periódicas de sus Juntas de Gobierno, designadas por ellos. Los Colegios Profesionales serian propiamente una administración pública, en la que no tiene entrada el derecho de autoorganización en los términos que expone nuestra Carta Magna en los arts. 22 y 36 . Si fuera así, carecería de sentido la obligación que impone la Constitución a los Colegios de respetar la democracia en su funcionamiento y estructura interna.

Sin embargo, la STC 12/87, marca la diferencia del art. 36 con el 22 en materia de organización, contenido esencial del derecho de asociación, afirmando que los estatutos de los Colegios Profesionales constituyen una norma de organización ajena a la libertad de asociación de que trata el art. $22 \mathrm{CE}$.

Si bien, en las SSTC $89 / 89$ y 131/89, el Tribunal Constitucional afirmó que los Colegios Profesionales constituyen una realidad jurídica de base asociativa y régimen particular distinta de la de las asociaciones de naturaleza privada, no entró a diferenciar las peculiaridades del régimen asociativo de los colegios sino que partió de la premisa de asumir como constitucional, a modo de verdad absoluta, el régimen legal ostentado por éstos en el momento histórico, el de corporación pública.

Por todo lo expuesto, no es de extrañar que el Tribunal Supre$\mathrm{mo}^{18}$ haya argumentado que en base a que los Colegios son públicos por su composición, por su organización y por las funciones públicas que tienen atribuidas o delegadas por la ley, excepcionan el derecho de libertad de asociación.

En todo caso, es innegable que la base del Colegio Profesional es la asociación y que son las funciones y un régimen jurídico específico los que le podrán caracterizar como una asociación de naturaleza específica, un Colegio Profesional.

Que la base del Colegio Profesional sea asociativa no ha sido discutido por el Tribunal Constitucional ${ }^{19}$, sino que lo ha afirmado. Esto significa que a salvo de las peculiaridades, el régimen jurídico constitucional del derecho fundamental de asociación y, en concreto, su con-

18 STS 27 de diciembre de 1983, RA 6836.

19 STC 89/1989, de 11 de mayo. 
tenido esencial debiera aplicarse a los Colegios, ya que de otro modo, no tendría sentido alguno afirmar que aquéllos en el fondo son formas de asociación. Sin embargo, esta afirmación choca frontalmente con las conclusiones obtenidas por el Tribunal Constitucional relativas a la constitucionalidad de la adscripción forzosa o la carencia de libertad de autoorganización en el marco del art. 22 CE.

El contenido asociacional de los Colegios profesionales es indiscutible. Por ello, debe aceptarse como válida la afirmación de que la Constitución, al reconocer a los Colegios Profesionales, se está refiriendo a un tipo de asociación específica, a unas asociaciones con un punto en común, que es que sus miembros tengan una misma titulación. Por ello, adquiere sentido que la redacción del precepto haga referencia a las peculiaridades, lo que indudablemente exige un genus, que no es otro que el derecho de asociación.

Esta interpretación constitucional no es novedosa ya que nuestra Constitución prevé una gran variedad de asociaciones específicas. Así, el sindicato, que tiene también una finalidad específica otorgada por la Constitución, la defensa y promoción de los intereses de los trabajadores, es también una asociación, a la que, en claro paralelismo con los Colegios Profesionales, el constituyente igualmente le impone la democracia interna (art. 7). Lo mismo ocurre con las asociaciones empresariales y partidos políticos, que se rigen por el art. $22 \mathrm{CE}$. Junto a todas ellas, existen otras asociaciones, que no tienen relevancia constitucional y a las que no se les imponen normas de estructura y funcionamiento, como las de consumidores y usuarios (art. 51 CE) o las organizaciones profesionales (art. $52 \mathrm{CE}$ ).

En definitiva, de acuerdo con Lucas Murillo ${ }^{20}$, puede afirmarse rotundamente que el constituyente ha previsto un haz de asociaciones específicas de diverso carácter, y que esto es una de las características definitorias de nuestra Constitución. Ahora bien, si todas ellas son asociaciones, y existe un derecho específico de asociación, éste ha de considerarse con Santamaría Pastor ${ }^{21}$ como derecho común aplicable a todas las asociaciones especiales creadas en nuestra Constitución, siempre que no exista contradicción con lo expresamente previsto en su derecho específico.

20 Lucas Murillo de la Cueva, E.: El derecho de asociación, Tecnos, Madrid, 1996, pág. 83 y ss.

21 Santamaría Pastor, J. A.: "Comentario al art. 22 CE", en Comentarios a la Constitución, dir. F. Garrido Falla, Civitas, Madrid, 1985, págs. 427 y ss. 
Por todo ello, es de considerar que el Tribunal Constitucional a la hora de valorar el régimen jurídico constitucional de los Colegios Profesionales debe abstraerse de su regulación legal en este momento histórico determinado, debe delimitar su contenido mínimo sin necesidad de basarse en la actual legislación que define al Colegio Profesional como una corporación pública, y debe definir las peculiaridades que han de venir necesariamente referidas a algo, que ha de considerarse que es el derecho de asociación. Estas peculiaridades tienen un límite que es el respeto del contenido esencial del derecho, no sólo del art. 36 sino también del art. 22 en todo aquello que no se oponga a aquél, y en concreto: el derecho a crear asociaciones, el derecho a pertenecer libremente a ellas y el derecho de autoorganización. Este último derecho habría de matizarse, ya que frente a la libertad absoluta que permite el art. 22. CE, el art. $36 \mathrm{CE}$ impone las reglas democráticas en el funcionamiento interno y estructura de los Colegios Profesionales.

\section{LA COLEGIACIÓN OBLIGATORIA}

\subsection{Exposición del problema}

El debate de fondo, sobre los Colegios Profesionales y su constitucionalidad, gira en torno a la colegiación obligatoria. Dice el Tribunal Constitucional22 que los Colegios Profesionales «aún siendo en cierto modo asociaciones, constituyen una peculiar o especial clase de ellas con reglas legales propias, distintas de las asociaciones de naturaleza jurídico privada, es claro que no puede serles aplicable el régimen de éstas".

Ahora bien, reconocidas como asociaciones peculiares, cabe plantearse si el legislador, al regular dichas peculiaridades, a las que así llama también la Constitución en otros preceptos como el derecho de libertad sindical, queda sujeto al contenido esencial del derecho (art. 53.1 CE) de asociación, tanto en su vertiente positiva: el derecho a crear asociaciones como en su vertiente negativa: el derecho a no constituir asociaciones y el derecho a no asociarse o afiliarse.

22 STC de 16 de enero 1996, reiterando lo expuesto en la STC 89/1989, de 
Como dice Gallego Morales ${ }^{23}$, esas peculiaridades se han de predicar de un genus, que ha de ser necesariamente el de asociación, sin que puedan argüirse en contra de tal opinión razonamientos de índole sistemática. Además, si nuestra Carta Magna hace referencia a peculiaridades ${ }^{24}$, no puede interpretarse cosa diferente.

Sin perjuicio de lo anterior, hay recordar que las asociaciones de Jueces, Magistrados y Fiscales son, en palabras de nuestra Constitución "asociaciones profesionales" y en ellas se predica la libertad de asociación en su vertiente negativa. Tan profesionales como lo Jueces, Magistrados o Fiscales, habría de calificarse a los integrantes de los Colegios Profesionales, en cuanto que la propia Constitución en su art. 36 al referirse a los Colegios los califica de "profesionales" y además los vincula a "profesiones tituladas". Resulta poco lógico, cuando menos, que entre los Jueces, Magistrados o Fiscales, que integran un poder del Estado, sea posible la libre asociación, pero entre otras profesiones, de lo más variadas, sea limitado dicho derecho existiendo obligación de asociación.

Es aún más notable esta limitación si nos atenemos a que es la ley, que no los Colegios Profesionales, la que ha de regular el ejercicio de las profesiones, por lo que son los tribunales ordinarios los que legítimamente han de velar por que se cumpla la ley, sin perjuicio de posibles trámites previos ante los colegios, que no pueden impedir el acceso a la vía jurisdiccional. Los Colegios no regulan el ejercicio de las profesiones que defienden, ni tampoco pueden imponer sanciones sin permitir su revisión en vía jurisdiccional. Los Colegios Profesionales quedan igual de sujetos a la legalidad que cualquier otra asociación y su colegiados tienen igual acceso a los tribunales por temas profesionales y deontológicos que si estuvieran integrados en una asociación de libre afiliación.

23 Gallego Morales, A. J., Colegios profesionales y sindicatos: confluencias $y$ tensiones, Comares, Granada, 1996, pág. 116. En contra están FERNÁNDEZ FARRERES, G.: Asociaciones y Constitución, Civitas, Madrid, 1987, y GARCíA MuRCIA, J.: «Sindicación y Colegios profesionales en la doctrina del Tribunal Constitucional», en VV.AA., VII Jornadas Andaluzas de Derecho del Trabajo y Relaciones Laborales, CARL, Sevilla, 1991, pág. 58.

24 Nótese que el art. 28.1 CE así como el art. 103.2 CE también hacen mención a peculiaridades, referidas al derecho de libre sindicación. Además es de indudable interés la diferencia que crea el constituyente en torno a cuatro conceptos diferentes: exclusión, exceptuación, limitación y peculiaridad. Esta última siempre deberá respetar el contenido esencial del derecho. 


\subsection{La tutela del interés general}

Nuestro Alto Tribunal juzgando un caso relativo a los colegios de médicos ${ }^{25}$ entiende que no hay vulneración del art. $22 \mathrm{CE}$ en la colegiación obligatoria ya que «queda justificada por razón de la tutela del interés general que concurre..., en el ejercicio de la profesión médica: disciplina profesional, normas deontológicas, tutela de la buena fe de terceros..., cuya protección va unida a la de valores y derechos constitucionales como la salud, la sanidad y la vida e integridad física de los ciudadanos, que están en juego con ocasión del ejercicio de la profesión médica".

La tutela del interés general no lleva implícito, a nuestro modo de ver, que la adscripción a los colegios sea obligatoria. La tutela del interés general se puede llevar a cabo de igual manera con asociaciones de libre afiliación, ya que por encima de las decisiones colegiales cabe siempre una revisión jurisdiccional, que puede, $y$ en muchos casos es, contraria a aquéllas. El Colegio Profesional no es, por tanto, el órgano único y último de tutela del interés general.

En el caso de la sentencia con que se iniciaba este epigrafe, el ciudadano siempre podrá pedir responsabilidades o daños y perjuicios a un médico colegiado que haya actuado, desde su punto de vista, incorrectamente de acuerdo a la práctica médica o bien, en contra del derecho constitucional de la salud, la vida o la integridad física, ante los Tribunales de Justicia, bien a través de la vía jurisdiccional penal o bien civil.

La tutela del interés general está asegurada al margen de colegios con adscripción obligatoria porque, por un lado, si quedan afectados derechos fundamentales, como el derecho a la vida, siempre es posible su tutela vía art. 53.2 CE y, por otro lado, al ser la ley la que regula el ejercicio de las profesiones, siempre es posible exigir su cumplimiento ante la Jurisdicción competente en vía ordinaria. Todo ello con independencia de las resoluciones de los Colegios Profesionales implicados.

Por otro lado, entre colegiados y en clara referencia a normas deontológicas y de control del ejercicio, el Colegio Profesional puede resolver controversias, pero no es, en ningún caso, un órgano al que las partes quedan sometidas con obligación legal de acatar su decisión 
a la manera de un tribunal de justicia, ni siquiera se puede imponer el arbitraje o la obligación de resolución de conflictos en vía extrajudicial. Los colegiados siempre podrán recurrir la decisión del Colegio Profesional ante la vía jurisdiccional ordinaria, por lo que la labor colegial de control queda finalmente resuelta por el Poder Judicial. A este respecto hay que resaltar que los derechos de los colegios sobre sus colegiados no puede primar sobre el principio de legalidad, de tal manera que aquéllos no podrán sancionar sin cobertura normativa suficiente, tal y como ha puesto de manifiesto de forma reiterada el Tribunal Constitucional26, ya que el art. 25.1 CE no permite a los poderes públicos imponer sanciones sin cobertura normativas suficiente por medio de una disposición legal27.

Frente al régimen disciplinario que necesariamente ha de estar publicado en el Boletín Oficial correspondiente por conllevar el principio de legalidad la reserva de $\operatorname{ley}^{28}$ y la exigencia de la predeterminación normativa de las conductas ilícitas y de las sanciones correspondientes ${ }^{29}$, las normas de deontología profesional aprobadas por los Colegios Profesionales o sus respectivos consejos superiores u órganos equivalentes, dice nuestro Alto Tribuna| ${ }^{30}$, que no constituyen simples tratados de deberes morales sin consecuencia en el orden disciplinario, sino por el contrario determinan obligaciones de necesario cumplimiento por los colegiados y responden a potestades públicas que la ley delega en favor de los Colegios junto con la facultad disciplinaria en el orden profesional y colegial, sin necesidad de publicación en el BOE u otro diario oficial, siempre que se aplique razonablemente, Y sujeta siempre a revisión por los órganos judiciales competentes.

En nuestros días, los colegios parecen ser cada vez más conscientes de que han de adaptarse a la vida actual en la que el motor es

26 STC 93/92, de 11 de junio, reiterada posteriormente en las SSTC de 23 de noviembre de 1996, de 30 de septiembre de 1996, de 17 de enero de 1997.

El Tribunal Constitucional ha afirmado que "la función de ordenar la profesión que contempla con carácter general el art. 3 LCP al socaire del art. $36 \mathrm{CE}$, solamente puede ser ejercida dentro de los límites marcados por las atribuciones otorgadas por ley, las cuales deben ser objeto de una interpretación estrictan, STC 83/1984, de 24 de julio, doctrina que ha sido reiterada en la STC 93/92, de 11 de junio.

27 STC 93/1992, de 11 de junio.

28 STC 80/1983, de 10 de octubre.

29 SSTC 42/1987, de 7 de abril; 89/83, de 2 de noviembre.

30 STC 219/1989, de 21 de diciembre. 
la economía, la empresa. Por ello, normas para el ejercicio de la profesión, que se basaban en la protección de derechos y valores tanto de colegiados como de terceros, están cambiando. Así, colegios tan clásicos o tradicionales como los de abogados han abierto las puertas a la posibilidad de que sus colegiados publiciten sus servicios jurídicos, si bien bajo el control del propio colegio. Asimismo, el Consejo General de la Abogacía ha eliminado recientemente la prohibición de la quota litis, o lo que es lo mismo, permite que el profesional cobre un porcentaje en función de los resultados $y$, además se permite que el profesional actúe otorgando descuentos e incluso sin cobrar nada.

Con estas medidas, que son continuación de las adoptadas con la promulgación del Real Decreto Ley 5/1996, de medidas liberalizadoras en materia de suelo y Colegios Profesionales, comienza a ampararse la libertad de empresa y competencia ${ }^{31}$ (art. $38 \mathrm{CE}$ ) que colisiona ocasionalmente con los Colegios Profesionales.

\subsection{El principio pro libertate}

Resulta incuestionable que la doctrina constitucional así como la Ley de Colegios Profesionales, se contraponen al principio pro libertate, en materia de creación y pertenencia a asociaciones, sindicatos y cualquier organización, que inspira nuestra Constitución. Por ello, cabe plantearse si el Tribunal Constitucional ha estudiado el tema de adscripción obligatoria a los Colegios Profesionales de una manera tan exhaustiva y rigurosa como se ha hecho con otras asociaciones, también con funciones públicas, como las Cámaras Agrarias o las Cámaras de Comercio.

El Tribunal Constitucional se ha limitado, en los diversos casos en que se le ha planteado, a determinar la naturaleza jurídica de los Colegios Profesionales y las consecuencias de su carácter de corporación de derecho público, pero sin entrar a valorar sobre el fondo del

31 Se da respuesta así a un Informe del Tribunal de Defensa de la Competencia que, a su vez, atendía a las recomendaciones del Informe de la OCDE y a las consideraciones, que con fecha 11 de febrero de 1991, el Director General de la Competencia de la Comisión Europea formuló respecto a la legislación española sobre Colegios Profesionales, ante el planteamiento de la situación de restricción de la competencia que estaria amparando la legislación española sobre dichas corporaciones. Sobre este informe ver en IBÁÑEZ GARCIA, I.: Defensa de la competencia y Colegios Profesionales, Dykinson, Madrid, 1995. 
asunto, abstrayéndose del diseño legal actual, ya que es evidente que no todas las profesiones necesitan de un colegio y que no todas las profesiones tituladas afectan al interés general. Por consiguiente, no debe ser aceptable una generalización de constitucionalidad del actual régimen jurídico de los Colegios Profesionales cuando de ella se derivan posibles limitaciones de derechos.

El Tribunal Constitucional no ha fijado una doctrina clara sobre los casos concretos en que una profesión ha de contemplarse en el marco de los Colegios Profesionales y su ejercicio ha de ir precedido de colegiación obligatoria. Inicialmente el Tribunal Constitucional consideraba que debia tratarse de profesiones tituladas que afecten a derechos fundamentales o bienes constitucionalmente relevantes ${ }^{32}$. Sin embargo, esta doctrina se ha visto ampliada recientemente en la STC de 1 de octubre de 1998 que permite la colegiación obligatoria sólo con la invocación genérica por el colectivo profesional de cualquier bien o interés constitucional.

A la vista de ello, es de considerar imprescindible el estudio de otras sentencias, del mismo órgano, en las que ha establecido una doctrina sobre qué ha de valorarse para que la obligatoriedad de la adscripción a una asociación pueda ser considerada constitucional, y su posterior comparación con los Colegios Profesionales, así como la consiguiente posible vulneración del derecho de libertad de asociación.

El Tribunal Constitucional a raíz de dos recursos de inconstitucionalidad ${ }^{33}$ en materia de Cámaras Agrarias, resolvía si la adscripción obligatoria a las mismas, establecida tanto en la ley catalana como en la de las Cortes Generales, vulneraba los derechos de asociación y libertad sindical, así como el régimen de organizaciones profesionales en defensa de los intereses económicos propios del art. $52 \mathrm{CE}$. En ambas sentencias 132/1989 y 139/1989 se declaró la inconstitucionalidad de la adscripción obligatoria a dichas Cámaras por entender que se conculcaban tanto el derecho de asociación como el de libertad sindical. En relación al recurso de inconstitucionalidad de la ley catalana $^{34}$, entiende nuestro alto Tribunal que ninguno de los cometidos funcionales previstos para las Cámaras Agrarias justifica la adscripción

32 STC 111/1993, 25 de marzo.

33 SSTC 132/1989, de 18 de julio y 139/1989, de 20 de julio. Basándose en la doctrina emanada en ellas se dictan otras dos sentencias como son la 113/1994, de 14 de abril, y 179/1994, de 16 de junio.

34 Ley 18/1985 del Parlamento de Cataluña. 
obligatoria dado que son susceptibles de ser cumplidos sin necesidad de acudir a la excepcionalidad de la pertenencia obligatoria a las mismas de los profesionales del sector agrario. Por consiguiente crea una doctrina en la que la adscripción obligatoria sólo es aceptable si afecta al interés público y si además existe imposibilidad o al menos dificultad en conseguir la finalidad pública que tiene encomendada sin acudir a dicha obligatoriedad.

Esta doctrina fue aplicada también para enjuiciar la constitucionalidad de la adscripción obligatoria a las Cámaras de la Propiedad Urbana $^{35}$ y a las Cámaras de Comercio, Industria y Navegación.

Con respecto a éstas últimas, la STC 179/1994, de 16 de junio, declaró también la inconstitucionalidad de la adscripción obligatoria que preveía la entonces vigente Ley de 1911. Sin embargo, este criterio fue cambiado poco después a raíz de la cuestión de inconstitucionalidad n. ${ }^{\circ} 1027 / 1995$, resuelta por el Pleno el 12 de junio de 1996, en relación a los arts. 6, 12 y 13 de la Ley 3/1993, de 22 de marzo, Básica de las Cámaras Oficiales de Comercio Industria y Navegación. Esta segunda sentencia mantiene la adscripción obligatoria con base en la dificultad de obtener los fines de esta Corporación sin recurrir a la adscripción forzosa, tal y como anticipaba ya el Preámbulo de la ley, lo que justifica la asunción por las Cámaras de las funciones públicas que se les atribuye "ante la imposibilidad de que fuesen desarrolladas eficazmente por una multiplicidad de asociaciones representativas de intereses muchas veces contrapuestos». ElTribunal Constitucional en esta sentencia dice que «ni las funciones consultivas, ni las certificantes, ni las de llevanza del censo de empresas ni, finalmente las de apoyo y estímulo a la exportación son actividades cuyo cumplimiento no sea fácilmente atendible sin necesidad de acudir a la adscripción forzosa a una corporación de Derecho Público» (FJ $7^{\circ}$ ). Además elTribunal Constitucional considera que las Cámaras de Comercio, uen cuanto organizaciones profesionales encuentran su apoyo en el art. $52 \mathrm{CE}$ con el que no contaban otras Cámaras" (FJ $10 .^{\circ}$ ) y no en el art. 22 o art. 28 CE ya que estos entes tienen su origen, no en un pactum asociationis sino en un acto de creación estatal. Por ello, "si respecto de estas corporaciones no aparece la libertad positiva de asociación, los aspectos negativos de ésta, habrán de operar con serias modulaciones".

35 STC 113/94, de 14 de abril, en la que se declaró la inconstitucionalidad de la adscripción obligatoria, y que ha llevado a la casi nula actividad de estas cámaras. 
Un estudio en detalle de la ley de 1911 y de la vigente de 1993, así como de las correspondientes sentencias del Tribunal Constitucional conducen a concluir que las diferencias en materia de adscripción no son diferentes y no justifican, en derecho, los tan distintos y contrarios pronunciamientos constitucionales, que han habido.

Como indica Gallego Morales ${ }^{36}$, la metodología para determinar cuándo debe producirse excepcionalmente la obligatoriedad de adscripción está claramente expuesta: primero hay que analizar el cometido funcional asignado a las Corporaciones y en segundo lugar, determinar si tales cometidos pueden ser cumplidos con independencia de que exista una obligación asociativa.

Sin embargo, no se ha empleado para valorar la constitucionalidad de la obligatoriedad en la adscripción de Colegios Profesionales, lo que hubiera supuesto un estudio de las funciones que éstos tienen atribuidas, de tal manera que si pueden ser realizadas sin necesidad de la adscripción obligatoria ésta habría de considerarse inconstitucional de acuerdo con los parámetros señalados.

\subsection{La aplicación de los criterios jurisprudenciales del Tribunal Constitucional a los Colegios Profesionales}

De acuerdo con la Ley de Colegios Profesionales, todo sujeto que ostente la titulación requerida y reúna las condiciones señaladas estatutariamente, tiene derecho a ser admitido. Por consiguiente, el Colegio, tal y como la propia Constitución señala, gira alrededor del ejercicio profesional de profesiones tituladas.

Sin embargo, los Colegios están asumiendo funciones privadas, que como indica Sainz Moreno y Torres del Mora| ${ }^{37}$ atraen la colegiación de titulados que no son profesionales, llamados no ejercientes, con lo que se desfigura el sentido de aquéllos, se desnaturaliza su composición, sus decisiones y su significado real en la vida colectiva.

Aún así, esas funciones privadas como son la mutualidad, servicios médicos o acuerdos con empresas privadas para conseguir ventajas en el mercado, junto con otras actividades que se proyectan más

36 Gallego Morales, A. J.: Colegios profesionales..., obra citada, pág. 122.

37 SAINZ MoRenO, F:: "Comentario al art. 36", obra citada, pág. 645; TORRES del Moral, A.: Principios de Derecho Constitucional Español, obra citada, pág. 346. 
allá de la propia profesión y que benefician a no colegiados, como pueden ser concursos abiertos a toda la población, no tienen por qué ser sufragadas por la cuotas de todos los colegiados que han de adscribirse obligatoriamente a estas Corporaciones, de tal manera que ha de plantearse si es constitucional la suspensión o pérdida del ejercicio profesional en caso de impago, por lo que seria interesante que el Tribunal Constitucional se pronunciara sobre la atribución por ley de esas funciones privadas y sobre su financiación obligatoria. A este respecto ha de concluirse que se estaria limitando la libertad del individuo para ejercer su profesión con base en una cuestión que no afecta al interés general, ni queda justificado en la vulneración de otros derechos fundamentales o valores constitucionales.

Las funciones propias de los Colegios están enumeradas en el art. 5 LCP, que podríamos sistematizar en dos grandes grupos: la ordenación del ejercicio profesional, y en concreto, en materia de retribución, intrusismo, conciliación y arbitraje, ordenación deontológica y disciplina profesional, $y$ lealtad profesional, y por otro lado, el ejercicio de funciones de colaboración.

Estas funciones en buena medida pueden ser realizadas por otro tipo de asociación de base voluntaria, ya que son las leyes, que no las normas colegiales internas, las que al final han de delimitar la actividad profesional y, por tanto, son losTribunales los que finalmente valoran el intrusismo o actuaciones contrarias a la legislación vigente ${ }^{38}$. La conciliación o arbitraje puede llevarlo a cabo cualquier asociación, no es necesario que se trate de Colegios Profesionales, ni mucho menos es competencia exclusiva de éstos. Por otro lado, en materia retributiva, el establecimiento de mínimos en los honorarios ha sido derogado en el Real Decreto Ley 5/1996, de 7 de junio, por atentar a la libre competencia, cuestión diferente de que el Colegio, como pueda hacerlo otra asociación, gestione el cobro de los honorarios, tal y como se hace a título de ejemplo en el Colegio de Ingenieros de Caminos, lo que constituye un servicio más que se ofrece al colegiado. En otro orden de cosas, las funciones de colaboración, coinciden en algunos casos con las que desempeñan en otros ámbitos los sindicatos u otras asociaciones profesionales.

En consecuencia, no puede admitirse la obligatoriedad de colegiación con base en la propia doctrina delTribunal Constitucional, esta-

38 Las resoluciones en materia sancionadora son recurribles ante la Jurisdicción Contencioso Administrativa. 
blecida respecto de las Cámaras Agrarias, dado que las funciones de estos colectivos, de una parte, pueden ser desempeñadas por otras asociaciones $y$, de otra, no siempre afectan al interés general.

\subsection{La STC de 1 de octubre de 1998}

En la sentencia del Pleno delTribunal Constitucional de 1 de octubre de 1998, siendo ponente el Sr. Gabaldón López, se plantea la infracción del derecho de asociación negativa, en el caso de un profesor de educación física que es condenado por intrusismo al no estar incorporado al "Colegio de Profesores y Licenciados de Educación Física».

Esta sentencia reitera, en gran medida, la doctrina que se ha expuesto hasta el momento, en materia de obligación de colegiación siempre que esté justificada por la necesidad de servir un interés público ${ }^{39}$, es decir, vinculada a la tutela de intereses generales. Se afirma asi en la sentencia de 1 de octubre de 1998, que "la calificación de una profesión como colegiada con la consiguiente incorporación obligatoria, requiere desde el punto de vista constitucional la existencia de intereses generales que puedan verse afectados 0 , dicho de otro modo, la necesaria consecución de fines públicos constitucionalmente relevantes", haciendo referencia a la relación entre la actividad profesional con determinados derechos, valores y bienes constitucionalmente garantizados, que podrán ser controlados por el Tribunal Constitucional.

Con esta base, nuestro alto Tribunal considera justificada la limitación del derecho de asociación en su vertiente negativa y por tanto considera constitucional la colegiación obligatoria que fija la ley para el caso del Colegio de Profesores y Licenciados de Educación Física, basándose en el mandato que hace la Constitución a los poderes públicos para que fomenten la educación física y el deporte (art. 43.3 CE) y en que ambas actividades aparecen estrechamente vinculadas con la salud añadiendo que, dado que los destinatarios de las actividades de los profesores de educación física son, en una buena parte de los casos, menores de edad, se ha de exigir mayor preparación y responsabilidad para quienes asumen dicha docencia. De esta manera el Tribunal Constitucional amplía notablemente la exigencia que establecía la STC 111/93, que era que las profesiones tituladas debían afectar a 
derechos fundamentales o bienes constitucionalmente relevantes para que la actividad profesional fuera objeto de un Colegio Profesional del art. $36 \mathrm{CE}$.

Esta sentencia tuvo, con acierto, un voto particular del Magistrado D. Vicente Gimeno Sendra, quien alertaba de esta peligrosa doctrina, que respalda que pueda justificarse la colegiación obligatoria en cualquier bien o interés constitucional.

Evidentemente, tal y como expone el voto particular, con esta doctrina se está contribuyendo a conculcar los derechos fundamentales a la libertad y de asociación.

Cualquier profesión titulada, no ya sólo las clásicas profesiones liberales, puede tener su colegio, que puede imponer la afiliación obligatoria basándose en un bien o interés constitucional, que no tiene por qué afectar al interés general ni estar ligado a derechos fundamentales o bienes constitucionales relevantes. Las posibilidades de colegios de profesiones no sólo universitarias sino de cualquier otro rango, $y$ con adscripción obligatoria, tienen con esta nueva doctrina amparo constitucional. Frente a la libertad de asociación que predica nuestra Constitución, a golpe de jurisprudencia se ponen las bases para volver al gremialismo medieval.

\subsection{La doctrina constitucional y la doctrina del Tribunal Europeo de Derechos Humanos}

La doctrina del Tribunal Constitucional en materia de Colegios Profesionales no es innovadora, sino sencillamente reitera la del Tribunal Europeo de Derechos Humanos en materia de libertad de asociación negativa, art. $11 \mathrm{CEDH}$.

ElTribunal Europeo de Derechos Humanos, en la sentencia de 23 de junio de 1981 (asunto Le Compte Van Leuven y De Meyere) ${ }^{40}$ y sentencia de 10 de febrero de 1983 (asunto Albert y Le Compte), valora si la obligación de afiliación a la Orden de Médicos belga vulnera o no el derecho garantizado en el art. $11 \mathrm{CEDH}$ considerando que dicha Orden no puede revestir el carácter de una asociación, ya que es una institución de derecho público, constituida por el legislador y no por

40 Sobre esta sentencia, Rodriguez Piñero, M.: "Colegios Profesionales y Constitución", RL, n. ${ }^{\circ}$ 9, 1993, pág. 7. 
los particulares, integrada en la estructura del Estado $y$ con la finalidad de tutelar intereses generales, en concreto, velar por la protección de la salud, asegurando un cierto control público del ejercicio de la profesión médica.

También en el caso Sigurdur A. Sigurjonsson contra Islandia el Tribunal Europeo de Derechos Humanos valoró si estaba ante una asociación o ante una organización profesional de derecho público. En concreto, se detuvo a examinar la naturaleza de la asociación de conductores de automóviles denominada Frami, que asumía la defensa de los intereses profesionales y retenía facultades administrativas, como la concesión y revocación de licencias, concluyendo que era una asociación privada encuadrada en el art. $11 \mathrm{CEDH}$, y por tanto declaró contrario a dicho precepto exigir la afiliación para obtener la licencia de la explotación del taxi basando su fundamentación, como argumento de autoridad ${ }^{41}$, entre otros, en las normas y declaraciones producidas en el seno de la Asamblea Parlamentaria del Consejo de Europa y por el Comité de libertad de asociación del Consejo de Administración de la Oficina Internacional del Trabajo.

A la vista de la jurisprudencia delTEDH se podría concluir que el Tribunal Constitucional tiene razón al afirmar que es constitucional la obligación de colegiación, pero desde nuestro punto de vista hay que valorar, por encima de la jurisprudencia internacional en materia de derechos fundamentales, que es de indudable importancia, nuestra propia Constitución, pudiéndose afirmar que desde nuestra Carta Magna se puede fundamentar la libertad de adscripción a los Colegios Profesionales, en el marco del derecho de asociación.

\section{COLEGIOS PROFESIONALESY SINDICATOS}

\subsection{Dos asociaciones constitucionales diferentes con puntos en común}

Afirma nuestro Tribunal Constitucional, en sentencia de 16 de enero de 1996, que «la asociación para la defensa de intereses profesionales puede dar lugar a formas asociativas diferentes, reguladas por el ordenamiento jurídico de modo específicon. Una fórmula de defen-

41 Bandrés Sanchez Cruzat, J. M.: Derecho Administrativo y Tribunal Europeo de Derechos Humanos, Civitas, Madrid, 1996, pág. 48. 
sa de estos intereses son los Colegios Profesionales que el propio Tribunal Constitucional reconoce que mantienen su base asociativa a pesar de que les otorgue ciertas potestades públicas para garantizar el ejercicio de la profesión, asegurándose tanto la eficacia como la eventual responsabilidad en tal ejercicio ${ }^{42}$. Ahora bien, esa realidad jurídica de base asociativa tiene un régimen particular distinto del de las asociaciones privadas ${ }^{43}$.

Otra fórmula asociativa de defensa de los intereses profesionales es el sindicato de trabajadores. Esta asociación tiene una función definida constitucionalmente, defender y promocionar los intereses económicos y sociales de los trabajadores (art. 7 CE), y es reconocida como institución básica del Estado, junto con los partidos políticos (art. $6 \mathrm{CE}$ ) y las Fuerzas Armadas (art. $9 \mathrm{CE}$ ). Además, el derecho a la afiliación libre así como a la constitución de sindicatos viene reconocido en nuestra Constitución como derecho fundamental con el máximo de garantías jurisdiccionales y de regulación.

Con la legislación vigente, la obligación de pertenecer a un colegio es compatible con la afiliación a un sindicato. El Tribunal Supremo en la sentencia de 20 de noviembre de 1981 declaró que "una cosa es la colegiación profesional y otra la sindicación", doctrina que confirmó el Tribunal Constitucional a partir de la STC 123/1987, y reiteró en la STC 89/1989 en la que decía que "la adscripción obligatoria no impide en modo alguno que los profesionales colegiados puedan asociarse o sindicarse en defensa de sus intereses, ya que no puede afirmarse fundadamente que exista incompatibilidad o contradicción constitucional interna entre los artículos 22, 28 y 36 CE».

Colegios profesionales y sindicatos defienden intereses profesionales, sin embargo las diferencias entre ambas asociaciones son de indudable trascendencia. Mientras que el sindicato es institución básica del Estado, el Colegio Profesional no lo es, pero la ley le otorga la condición de corporación de derecho público. Mientras que el derecho de libertad sindical tiene reconocidas por el art. 53 garantías jurisdiccionales, con acceso al Tribunal Constitucional a través del recurso de amparo y, el art. 81 impone que su desarrollo se lleve a cabo por ley orgánica, el derecho de los Colegios Profesionales se tutela ante los 
tribunales ordinarios, sin procedimientos especificos de urgencia y sumariedad, y su desarrollo no necesita ley orgánica. Sin embargo, mientras que la Constitución predica la libertad de afiliación a los sindicatos, una ley preconstitucional impone la adscripción forzosa a los Colegios Profesionales.

A su vez hay aspectos en los que confluyen sindicatos y Colegios Profesionales. Ambos son asociaciones gremialistas $Y$ en ambos, el derecho común es el derecho de asociación del art. 22, que se aplicará en todo lo que no contradiga a los arts. 28.1 (que hay que relacionar con el art. 7) y el art. $36 \mathrm{CE}$. Tanto los colegios como los sindicatos tienen impuesta una limitación por la Constitución en su estructura interna y funcionamiento es la democracia interna. Los dos defienden intereses profesionales y para ello ambos tienen reconocidas unas funciones públicas de participación que se reflejan en temas como su audiencia por los poderes públicos, por ejemplo, cuando se tramita una legislación nueva que les puede afectar. Por otro lado, tanto las decisiones de los órganos de gobierno de sindicatos y de colegios son revisables jurisdiccionalmente, y aquellas están limitadas por la aplicación de la ley y de sus estatutos.

A la vista de todo ello, habrá de cuestionarse qué justifica que en un tema tan trascendente como la libertad de asociación negativa, una ley preconstitucional imponga en los Colegios Profesionales la adscripción forzosa, mientras que la Constitución y la ley orgánica de libertad sindical imponga la libertad de afiliación como contenido esencial del derecho, en el caso de los sindicatos. Asimismo habrá de valorarse si esa adscripción obligatoria supone un límite al derecho de libertad sindical.

\subsection{La defensa del interés de la profesión: dos ejemplos de confluencia}

\subsubsection{Introducción}

Los Colegios Profesionales son diferentes de los sindicatos, si bien la posición de unos y otros no es fácil de separar ${ }^{44}$ ya que aun- 
que la finalidad propia y específica de aquéllos sea la ordenación del ejercicio de la profesión, también contribuyen a la defensa y promoción de los intereses económicos y sociales de sus miembros, en clara consonancia con el art. 7 CE referido a los sindicatos $y$ asociaciones empresariales.

Ojeda ${ }^{45}$ se hace eco de la desigualdad entre sindicatos y Colegios Profesionales considerando que las diferencias circunstanciales entre ambos pueden desaparecer con una nueva regulación de los Colegios Profesionales, y arguyendo que, con la actual legislación, mientras que la función de los Colegios es "altruista», la de los sindicatos se puede calificar de egoista, diferenciación que hace en cierta manera la doctrina en base a la posición cuasi administrativa ${ }^{46}$ de los Colegios.

Sin embargo, en la práctica, las funciones propias de los Colegios son más privadas, en la línea de una asociación gremial o sindicato o asociación profesional, que públicas. Un ejemplo se encuentra en la progresiva asunción de competencias por parte de las Comunidades Autónomas de funciones que previamente tenían los colegios ${ }^{47}$ y en las medidas liberalizadoras que se están adoptando, que han sido ya referidas.

45 OJeDa AVILÉs, A.: Derecho sindical español, obra citada, pág. 139.

46 Tal y como dice SAINZ MORENO, "el hecho de que tengan atribuidas algunas funciones públicas no los convierten en Administración Pública, ya que dichas funciones atribuidas por la ley o delegadas por actos concretos de la Administración no agotan la naturaleza de los Colegios, sino que son funciones añadidas a los mismos". En "Comentario al art. $36 \mathrm{CE}$ ", obra citada, pág. 635.

En la misma línea está GARClA DE ENTERRIA, que dice que "lo más peculiar de estos entes corporativos es que tienen delegadas algunas funciones públicas, per no por ello pasan a ser entidades administrativas stricto sensu, sino que continúan siendo, por el contrario, entidades que se rigen por el Derecho Privado en todo cuanto excede de esas delegaciones estrictas (así su personal no es funcionario, ni sus actos y contratos son administrativos ni su dinero es público, etc.)", en "Opiniones sobre la Ley de Colegios Profesionales", diario Ya, 5 a 8 de mayo de 1973.

47 Un ejemplo está en los Colegios de Farmacéuticos y, por ende, el Consejo General de Farmacéuticos de España, que han sido vaciados de una de sus grandes competencias como es la tramitación y resolución de expedientes sobre nuevas aperturas, traspasos y traslados de oficinas de farmacia, resoluciones que lógicamente eran susceptibles de recurso contencioso administrativo, a partir del Real Decreto Ley 11/1996, de 17 de junio, sobre ampliación del servicio farmacéutico a la población, asumiéndose dichas competencias por las Comunidades Autónomas. 


\subsubsection{La legitimación procesal}

La defensa del interés de la profesión tanto puede llevarse a cabo por los colegios como por los sindicatos $u$ otro tipo de asociaciones ya que el art. 7.3. LOPJ establece que "los Juzgados y Tribunales protegerán los derechos e intereses legítimos, tanto individuales como colectivos, sin que en ningún caso pueda producirse indefensión. Para la defensa de estos últimos se reconocerá la legitimación de las corporaciones y grupos que resulten afectados o que estén legalmente habilitados para su defensa y promoción".

De esta manera, la legitimación de Colegios ${ }^{48}$ y sindicatos ${ }^{49}$ se hace extensible a todos los órdenes jurisdiccionales, más allá del reconocimiento expreso que hacía la antigua Ley de Jurisdicción Contencioso Administrativa en su art. $32^{50}$.

Por consiguiente, como indica Gallego Morales 51 , la LOPJ supone la legitimación del sindicato para ser parte en aquellos procesos en que tradicionalmente se ha reconocido legitimación a los Colegios Profesionales $y$, viceversa, la legitimación de los Colegios en aquellos otros en que el papel de parte se ha reservado al sindicato.

48 Art. 5.g) LCP: “Corresponde a los Colegios Profesionales el ejercicio de las siguientes funciones en su ámbito territorial: $g$ ) ostentar en su ámbito la representación y defensa de la profesión ante la Administración, Instituciones, Tribunales, Entidades y particulares, con legitimación para ser parte en cuantos litigios afecten a los intereses profesionales y ejercitar el derecho de petición, conforme a la Ley, sin perjuicio de los dispuesto en el apartado 3 del art. $10^{\circ}$ de esta ley".

49 Art. 20.1 LPL "Los sindicatos podrán actuar en un proceso en nombre e interés de los trabajadores afiliados a ellos que si se lo autoricen, defendiendo sus derechos individuales $y$ recayendo en dichos trabajadores los efectos de aquella actuación".

Ahora bien, sin perjuicio de esta representación, cabe también la posibilidad de que el Sindicato vaya como coadyuvante del trabajador en el procedimiento de trabajo.

Sobre este tipo de procesos individuales de trabajo y la equiparación de legitimación de sindicatos y colegios, ver en MORENO VIDA, M. ${ }^{a}$ N.: "La posible legitimación del sindicato en los procesos individuales de trabajo (particular examen de la Base 7.4 del Proyecto de la Ley de Bases de Procedimiento Laboral", REDT, n. 38,1989 , págs. 279 y ss.

50 Art. 32 LJCA: «Los Colegios oficiales, sindicatos, cámaras, asociaciones y demás entidades constituidas legalmente para velar por intereses profesionales o económicos determinados estarán legitimadas como parte, en defensa de estos intereses $y$ derechos".

51 Gallego Morales, A. J.: Colegios profesionales..., obra citada, pág. 251. 
Así, se podría plantear la legitimación del sindicato en un proceso penal sobre intrusismo, ya que de él se pueden derivar perjuicios económicos para los colegiados afiliados al sindicato, de los que éste ha de velar al amparo del art. $7 \mathrm{CE}$. En este tipo de procesos tradicionalmente era el Colegio el legitimado, dado que se trata de un aspecto que afecta al ejercicio de la profesión así como a la deontología. Por otro lado, el Colegio profesional tendría legitimación en procesos laborales en los que esté afectado un colegiado sujeto a una relación de trabajo, en el sentido técnico-jurídico, ya que el Colegio estaría habilitado por la LOPJ en cuanto que defiende intereses colectivos.

\subsubsection{La legitimación en la negociación colectiva}

Cuestión más conflictiva es que los Colegios, como los sindicatos, ostenten legitimación en la negociación colectiva, así como en otros tipos de acuerdos de alcance laboral.

Hueck y Nipperdey ${ }^{52}$ consideran que toda asociación de base obligatoria carece de capacidad convencional. Esta afirmación carece de fundamento constitucional, ya que la negociación se reconoce entre representantes de trabajadores y empresarios, no queda limitada a sindicatos y asociaciones empresariales. Dada la amplitud de los posibles sujetos de la negociación colectiva y la falta de limitación expresa constitucional es de considerar posible que los Colegios profesionales, pese a la adscripción obligatoria que en la mayoría de los casos existe, puedan ser sujetos del derecho previsto en el art. $37 \mathrm{CE}$.

Por su parte, Rodríguez Piñero ${ }^{53}$ considera que los colegios no son organizaciones reivindicativas, que utilicen la vía de la movilización y de la acción colectiva organizada, por lo que califica de dudoso que puedan ser parte en la negociación colectiva. Esta afirmación, no puede calificarse de estrictamente jurídica, ya que el hecho de que no se opte por vías reivindicativas no significa que no tengan derecho a ejercitarlas, o lo que es lo mismo, el no haber hecho nunca una huelga, o negociado un convenio no significa que no puedan hacerlo.

52 HueCK, A., y NiPPERDEY, H. C.: “Compendio de Derecho de Trabajo", trad. castellana por M. Rodríguez Piñero y L. E. de la Villa, Madrid, Revista de Derecho Privado, 1963, págs. 331 y ss.

53 Rodríguez Piñero, M.: “Colegios...", obra citada, págs. 3 y ss. 
Por consiguiente, debemos hacer un estudio desde la propia Constitución, más allá de la forma habitual de actuación de los Colegios, sobre todo por la diversidad de sus funciones $y$ acciones.

El art. 37 CE no especifica quiénes han de ser los representantes de los trabajadores y de los empresarios, razón por la que hay que estar por una interpretación amplia, sin perjuicio de que la negociación estatutaria recaiga fundamentalmente en los sindicatos ${ }^{54}$. De manera que inicialmente no existe impedimento constitucional para que los Colegios, igual que los sindicatos, puedan llevar a cabo negociaciones para la posterior firma de convenios colectivos, que revestirán la forma de negociación extraestatutaria.

Sin embargo, mientras que cuando nos referimos a sindicatos pensamos directamente en trabajadores por cuenta ajena, al tratar de los Colegios podemos encontrarnos con trabajadores autónomos, profesionales liberales, empresarios y también trabajadores por cuenta ajena ${ }^{55}$. Por lo que, en función de la profesión que ampara el Colegio, éste podrá asumir la parte de los trabajadores o la de los empresarios.

Ahora bien, el Colegio no puede erigirse como único canal para la negociación colectiva, por lo que serán los colegiados quienes, bien a través del Colegio, bien a través de otra asociación o sindicato, negocien los convenios colectivos o pactos laborales.

Esta posibilidad de participación de los Colegios en asuntos laborales ha hecho pronunciarse a la doctrina en el sentido de que deben establecerse las fronteras de actuación entre sindicatos o asociaciones profesionales y Colegios, de tal manera que no existan interferencias funcionales. Sin embargo estas afirmaciones carecen de respaldo constitucional dado que tanto los Colegios Profesionales como la asociación sindical o profesional, pueden defender los intereses propios de sus afiliados, lo que incluye sin lugar a dudas, la defensa de intereses laborales, en cuanto afecten a la profesión.

54 Gallego Morales, A. J., hace un estudio pormenorizado y comparativo de la posibilidad de negociación colectiva de los colegios valorando la legislación puramente laboral, al que nos remitimos. En Colegios profesionales..., obra citada, págs. 254 y ss.

55 De este tipo es el Colegio Profesional de empleados de notarías, que si bien comenzó a negociar un convenio colectivo, finalmente los sindicatos, que los mismos empleados y colegiados constituyeron, se mostraba como canal negociador más satisfactorio. Sobre este tema en particular ver GoerLICH PESET, J. M. ${ }^{a}$, La relación de trabajo de los empleados de notarías, Edersa, Madrid, 1987, pág. 78. 


\subsection{La limitación que ejerce el Colegio Profesional en el derecho de libertad sindical}

Es indudable la confluencia en funciones de defensa de los intereses profesionales entre los sindicatos y Colegios Profesionales, tanto en aspectos de funciones privadas como públicas de defensa de intereses profesionales. Esto supone que el trabajador que tenga obligación de adscribirse a un determinado Colegio profesional exigirá a éste que ejerza todas esas funciones, para las que está habilitado de forma legal, y le defienda en sus intereses profesionales, evitando, por tanto, la afiliación a un sindicato para que también le defienda, al que no tiene obligación de pertenecer.

Además el Colegio Profesional, con base en la adscripción obligatoria, será el más representativo de los intereses del colectivo a quien represente, por encima del sindicato, que por estar basado en la libertad, no reunirá a tantos afiliados de un determinado ámbito funcional y territorial, lo cual será determinante en el ejercicio de funciones públicas, sobre todo de participación con los poderes públicos.

A la vista de ello, con el hecho de obligar a la colegiación para poder ejercer, se está beneficiando legalmente al colegio frente al sindicato, lo cual supone claramente un límite a la libertad sindical y ha ser calificado de contrario a nuestra Constitución.

El Colegio Profesional como el sindicato es una asociación, tal y como se ha venido afirmando a lo largo de este trabajo. Sin embargo, nuestra Constitución otorga mayor relevancia al sindicato: es una institución básica del Estado, frente al Colegio al que le hace depender de las peculiaridades que establezca el legislador. Además la Carta Magna reconoce el derecho de libertad sindical como derecho fundamental en la sección $1 .^{a}$, por encima del derecho de los Colegios Profesionales, que está en la sección $2 .^{a}$, de derechos y deberes.

El constituyente ha querido sin lugar a dudas impulsar el sindicato frente al Colegio profesional. Recordemos que en la redacción definitiva del texto constitucional, los colegios fueron desterrados del título preliminar, donde están las instituciones básicas del Estado, quedando sólo en el art. 7 CE los sindicatos y asociaciones empresariales.

Desde un inicio, por lo tanto, se ha otorgado diferente valor al sindicato y al Colegio Profesional, y ello ha de tener reflejo en la legislación vigente. Por ello, carece de sentido que desde una ley que regula una asociación específica, como es el Colegio Profesional, que no tiene relevancia constitucional, se limite el ejercicio del derecho de 
libertad sindical, derecho fundamental, que se lleva a cabo a través del sindicato que es una asociación con relevancia constitucional y es institución básica del Estado.

Sin perjuicio de lo expuesto, al ser el sindicato y el Colegio Profesional asociaciones específicas constitucionales, ambas tienen un referente común, el derecho de asociación del art. $22 \mathrm{CE}$, que se aplica de forma subsidiaria a los especificos arts. 28.1 y $36 \mathrm{CE}$.

Por ello, es de considerar que si el art. 36 no hace referencia a la adscripción obligatoria a los Colegios Profesionales y sólo hace una encomienda al legislador para regular peculiaridades, éste viene obligado a respetar el contenido esencial del derecho y esas peculiaridades no pueden limitarle. De tal manera que como el art. 36 CE no establece que la adscripción a los Colegios Profesionales es obligatoria, y siendo aquellos asociaciones, ha de aplicarse subsidiariamente el art. 22, y por lo tanto respetarse en todo caso el derecho de libertad de asociación, incluso en su vertiente negativa, que es contenido esencial de este derecho.

Si la adscripción fuera voluntaria, como en los sindicatos, la labor de defensa de los intereses profesionales dependería realmente de los ciudadanos, que optarían por el sindicato o el colegio en función de quien llevara a cabo una mejor defensa de la profesión. Por ello, el ciudadano podría valorar más el derecho de autoorganización de estas asociaciones, sus estatutos, y podrá exigir su cumplimiento con libertad. Esto no tiene por qué afectar a derechos o valores constitucionales ya que, incluso ahora con la adscripción obligatoria a los Colegios, siempre queda abierta la vía jurisdiccional para tutelar los intereses de los colegiados y afilados frente a sus respectivas organizaciones, así como de los ciudadanos que puedan ver afectados sus derechos por el ejercicio de una determinada profesión.

\section{A MODO DE CONCLUSIONES}

Ahora bien, ¿cuál es la misión y el límite de actuación del Colegio Profesional? El Colegio Profesional no tiene definido por la Constitución una misión, por lo que esta podrá variar en función precisamente del derecho de autoorganización que se predica de toda asociación y por tanto de él. Los límites, por su parte, vienen impuestos por el respeto a las leyes y a la Constitución. 
En este momento hay que despejar dos grandes problemas. Por un lado, qué misión tienen los colegios en la práctica y cómo afecta a la Constitución. Y por otro lado, si el Colegio es acorde con los límites que tiene impuestos.

Empecemos por el segundo de los interrogantes. Cuando la Constitución en el art. 36 dice que la ley regulará el ejercicio de las profesiones tituladas, está imponiendo una actuación de los órganos de representación de la ciudadanía: al Congreso y al Senado. Por tanto, el Colegio no puede hacer una regulación de la profesión y consecuencia de ello es que no puede erigirse en controlador único e imprescindible del cumplimiento de la ley e imponer sanciones, ya que para ello están los Tribunales Ordinarios que son los encargados por la Constitución del control de la aplicación de las leyes. Por otro lado, el Colegio viene limitado por otros derechos fundamentales como el derecho a la igualdad, el derecho a la tutela judicial efectiva o el derecho al trabajo. Por tanto, las limitaciones que vienen impuesta por la Constitución son de indudable alcance. En otro orden de cosas, no puede delegarse el control del ejercicio de la profesión a los colegios. No puede por ejemplo dejarse la tutela de derechos y valores constitucionales como el derecho a la salud, la sanidad o la vida e integridad física en manos de los Colegios. No son éstos los que vienen encomendados por la Constitución para la defensa, control y tutela de los derechos. El Colegio profesional, a pesar de estar configurado como una corporación, no puede tener encomendadas esas funciones en exclusiva, de tal forma que justifique que todos los profesionales de una determinada titulación tengan que estar a él afiliados. El garante del interés general es el Estado a través de sus poderes, pero no un Colegio profesional. En este orden de cosas, cabe plantearse por qué entonces es necesaria la afiliación obligatoria ya que la labor de control y posterior denuncia, que es en definitiva la labor pública del colegio, la puede llevar a cabo también una asociación, de tal manera que desde la Constitución no tiene justificación la afiliación obligatoria, ni tampoco la existencia de un único colegio por profesión. Es de considerar que los Colegios, que son asociaciones gremiales, debieran poder crearse libremente en el marco de la legislación vigente y la adscripción es voluntaria. De tal forma que un abogado ha de poder elegir entre la asociación gremial o colegio que más le convenga, lo que comportará por otro lado, que el anquilosamiento existente en los colegios desaparezca y comiencen a trabajar pro su colegiados.

El Colegio, como asociación, sí puede autoorganizarse, que es contenido esencial del derecho, y ello lo ha de hacer en el marco de 
una ley que desarrolla las peculiaridades de su régimen juridico. Aun así, la amplitud de actuación del Colegio es indudable y puede, dentro de su marco interno, por ejemplo, crear un código deontológico para sus colegiados, cuyo incumplimiento puede sancionar, fijar cuotas, suscribir un póliza de responsabilidad para sus colegiados, gestionar mejoras en un seguro médico $u$ organizar anualmente un concurso de pintura o de mus. El margen de funcionamiento en la autoorganización en enorme. Asi el Colegio, a través de su Junta de Gobierno, que ha sido nombrada democráticamente, puede adoptar medidas que podrían impedir notablemente el acceso al ejercicio profesional, con lo que se vulneraría la constitución. Un ejemplo podría ser la obligación de tener que pagar unas cuotas anuales de un millón de pesetas. El titulado en paro difícilmente podrá acceder al ejercicio de la profesión y el derecho al trabajo en el art. 35 quedaría en entredicho. En este sentido el Colegio estaría actuando para controlar el ejercicio profesional limitativamente, cuando es de considerar que si el problema es el exceso de titulados, las medidas de control se tendrán que poner antes de que el titulado acceda a su condición.

A la vez se crean cuestiones tan paradójicas como la que ha tenido ocasión de juzgar el Tribunal Supremo en la reciente sentencia de 8 de marzo de 1999 (Sala 3. ${ }^{a}$ ). En este caso elTS desestimó el recurso interpuesto por el Colegio Oficial de Ingenieros Industriales de Madrid contra la sentencia delTSJ de Madrid que reconoció al solicitante, con título obtenido en la República Argentina y convalidado por el Ministerio de Educación, la colegiación con el título español de ingeniero industrial en la especialidad de Química. El colegio consideraba que si se le permitía la colegiación el actor quedaria habilitado par desarrollar todas y cada una de las especialidades que integran el título español de ingeniero industrial (mecánica, metalurgia, eléctrica, técnicas energéticas, organización industrial y química), si bien la sentencia apelada manifestaba que la colegiación se podía circunscribir únicamente a su especialidad.

Esta sentencia plantea dos problemas constitucionales. Por un lado, ya tratado en el fundamento jurídico segundo de la misma, la colegiación no puede hacer discriminación por razón de dónde se ha obtenido el título siempre que éste esté reconocido por el Ministerio de Educación en España. El segundo problema, es a mi modo de ver más interesante, se podría estar vulnerando el derecho de autoorganización que tienen los Colegios Profesionales.

En este proceso no habría duda de que el profesional sindicado tiene derecho a que su sindicato le represente de acuerdo con el art. 
20 de la Ley de Procedimiento Laboral, si bien, Gallego Morales ${ }^{56}$ considera que el tenor literal del art. 5.g) LCP es al respecto de mayor generosidad para con los Colegios Profesionales, que el art. $20 \mathrm{LPL}$, dado que los colegiados podrán presentar demanda particular además de la que en su defensa presente el Colegio ${ }^{57}$.

Esta postura, que no se comparte, es de considerar criticable, dado que, a pesar del silencio de la LCP, considero que ninguna organización puede actuar en nombre de un particular y presentar una demanda en su nombre y sustituirle ${ }^{58}$ procesalmente, en defensa del interés particular del sustituido. No en vano, la sentencia no se le impone al Colegio sino al particular, por lo que considero que podría existir indefensión, y la consiguiente vulneración del art. 24 CE, si no existe consentimiento expreso de éste a favor del Colegio, y ello a pesar de que ese interés particular pueda llega a afectar a los intereses de toda la colectividad, en cuyo caso el colegio podrá personarse velando por esos intereses colectivos pero no por los particulares sin consentimiento.

En este sentido parece ser más conforme a derecho la legitimación que tiene el sindicato así como su articulación legal.

56 Gallego Morales, A. J.: Colegios profesionales..., obra citada, pág. 252. En ella aporta sentencia de la Audiencia Provincial de Ciudad Real de 21 de abril de 1993, de la que dice que expresamente señala que la legitimación por sustitución de los Colegios para ejercitar ante los órganos jurisdiccionales las reclamaciones de honorarios debidos a sus colegiados es coexistente con la genuina $y$ auténtica legitimación del profesional mismo.

57 STS (Sala $4 .{ }^{9}$ ) de 7 de febrero 1987 y STS (Sala 1. ${ }^{9}$ ) de 20 de abril de 1989.

Esto puede plantear el problema de que un mismo asunto pueda ser resuelto de dos formas distintas y por consiguiente, el problema de su ejecución, ya que cada parte querrá que se ejecute la sentencia que le es más favorable.

58 La sustitución es la figura que mantiene la Sentencia de la Audiencia Provincial de Ciudad Real de 21 de abril de 1993. 